\title{
THE SINTERING PROCESS IN SNOW
}

\author{
By René O. Ramseier and Charles M. Keeler \\ (U.S. Army Cold Regions Research and Engineering Laboratory, Hanover, New Hampshire, \\ U.S.A.)
}

\begin{abstract}
The growth of bonds between snow grains or ice spheres has been variously attributed to surface diffusion, volume diffusion, and evaporation-condensation. To distinguish among these possible mechanisms the unconfined compressive strength of two groups of snow samples was determined as a function of time. One group was allowed to sinter under atmospheric conditions while the other group was kept immersed in silicone oil. The much lower rate of strengthening of the latter group suggests that evaporationcondensation must be the major mechanism of mass transport in snow under atmospheric conditions. The possible magnitudes of the various mass transfer coefficients are discussed.
\end{abstract}

RÉsumé. Processus de tassement de la neige. La croissance des bords limites entre des grains de neige ou des sphères de glace a été différemment attribuée à la diffusion de surface, à la diffusion de volume et à l'évaporation-condensation. Pour faire la distinction entre ces mécanismes possibles, la résistance par compression libre de deux groupes d'échantillons de neige a été déterminée en fonction du temps. Le premier groupe pouvait se tasser dans des conditions atmosphériques, alors que le second restait immergé dans de l'huile de silicone. La vitesse bien plus faible d'augmentation de la résistance du dernier groupe suggère que l'évaporation-condensation doit être le principal mécanisme du transport de masse dans la neige sous des conditions atmosphériques. Les grandeurs possibles des différents coefficients de transfert sont discutées.

Zusammenfassung. Die Sinter-Bildung in Schnee. Das Wachstum von Bändern zwischen Schneekörnern oder Eiskugeln wurde verschiedentlich auf Oberflächen-Diffusion, Volumen-Diffusion und VerdunstungsKondensations-Vorgänge zurückgeführt. Um zwischen diesen möglichen Vorgängen zu unterscheiden, wurde die unbegrenzte Druckfestigkeit zweier Gruppen von Schneeproben als Funktion der Zeit bestimmt. Die eine Gruppe konnte unter atmosphärischen Bedingungen aussintern, während die andere in Silikon-Öl eingetaucht blieb. Die viel niedrigere Geschwindigkeit der Druckverfestigung der zweiten Gruppe lässt darauf schliessen, dass Verdunstungs-Kondensations-Prozesse den Hauptanteil des Massentransportes in Schnee unter atmosphärischen Bedingungen verursachen. Die möglichen Werte der verschiedenen Massentransport-Koeffizienten werden diskutiert.

\section{INTRODUCTION}

The process by which ice and snow particles bond together at temperatures below the melting point has been termed sintering in analogy with the phenomenon known in powder metallurgy. The theory of growth of individual bonds has been well described by Hobbs and Mason (1964). Several experiments have been conducted to determine the process by which mass is transferred to the region of the bond (Kingery, I96o; Kuroiwa, I96 I ; Hobbs and Mason, I964; Ramseier and Sander, 1966); however, the interpretation of the results has been varied. This variation has been due in part to the nature of the experiments and in part to certain misconceptions of the theory of sintering. In experiments utilizing small spheres of ice brought in contact under controlled conditions, Kingery (1960) thought that surface diffusion was the principal mechanism of mass transfer whereas Kuroiwa concluded that volume diffusion was primarily responsible at temperatures above $-15^{\circ} \mathrm{C}$., and surface diffusion below that temperature. Hobbs and Mason (1964) corrected several mathematical errors and in addition pointed out that certain assumptions made using the original theory of sintering were unrealistic. Their work indicated that evaporation-condensation is the major mechanism by which sintering proceeds under normal atmospheric conditions.

More recently, in an attempt to use naturally occurring materials, Ramseier and Sander (r966) studied the time dependence of the unconfined compressive strength of snow, making the assumption that the strength of snow is a function of both the size and number of the intergranular bonds (Nakaya, I959; Ballard and Feldt, I966). By comparing activation energies and mass transport coefficients they found that their results supported the evaporation-condensation hypothesis. The experiment described in this paper was designed to test this hypothesis by varying the conditions under which the sintering process occurs. 


\section{Experimental Procedure and Results}

Two groups of compacted snow samples were prepared according to the procedures described by Gow and Ramseier ( 1963 ). The density of all samples was $0 \cdot 55 \pm 0 \cdot 0 \mathrm{o} \mathrm{g.} \mathrm{cm}^{-3}$ and all were sintered at $-10^{\circ} \mathrm{C}$. One group was placed in boxes sealed with plastic bags to maintain a saturated atmosphere. The other group was immersed in Dow Corning silicone oil (o.65 centistoke).

Periodically a number of samples were tested on a motorized soil test press to determine the unconfined compressive strength. The results are shown in Figure I. Each point represents the mean or 6 or 7 individual samples. The data points from the samples sintered in air were fitted by expression (I) (Curve $a$, Figure I) (Ramseier, I966).

$$
\sigma_{\tau}=\sigma_{\mathrm{f}}\{\mathrm{I}-\exp -[A \tau \exp -(E / R T)]\}
$$

where $\sigma_{\tau}\left(\mathrm{kg} . \mathrm{cm} .^{-2}\right)$ is the unconfined compressive strength at time $\tau$ and temperature $T$; $\sigma_{\mathrm{f}}$ is the final unconfined compressive strength of fully sintered snow; $A, E$, and $R$ are constants, $A$ depending on density and snow type, $E$ being the activation energy of the sintering process (10.18 kcal. mole ${ }^{-1}$, determined by Ramseier and Sander (1966)), and $R$ being the universal gas constant. $\tau$ is used rather than $t$ (real time) as the snow sample has an initial strength at $t=0$ due to the compacting process. This initial strength corresponds roughly to the strength the sample would gain as a result of sintering for 6 days (Ramseier and Sander, 1966). The two points that fall well below the curve at 29 days are thought to do so because of some aberration in the testing procedure that day.

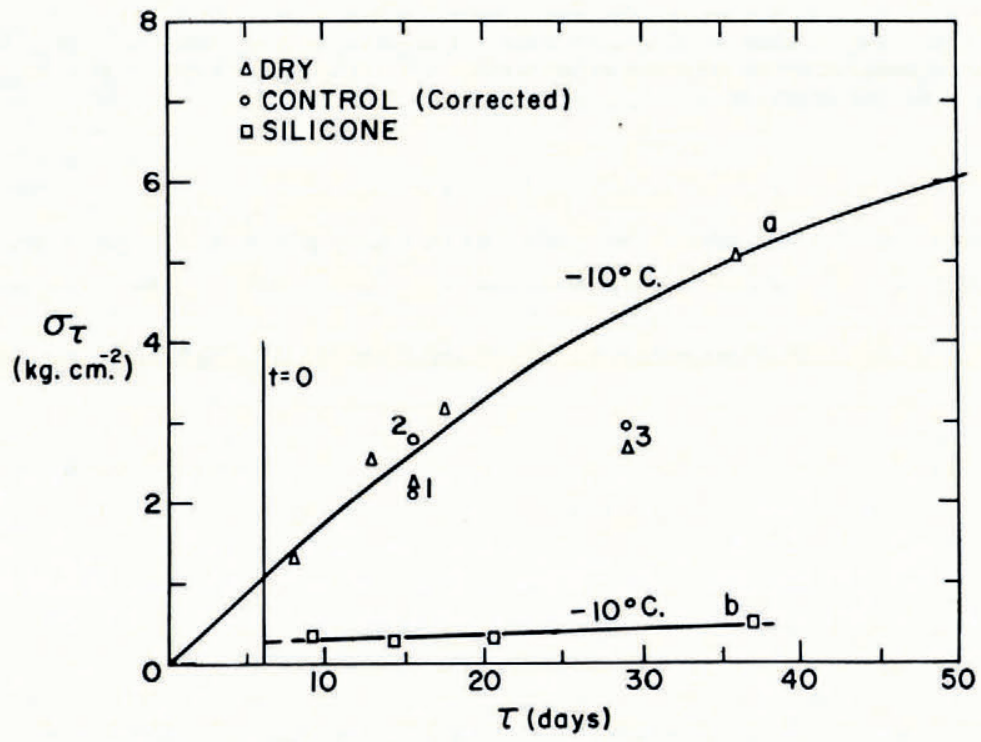

Fig. I. Sintering curves of snow (a) under atmospheric conditions, $(b)$ in silicone oil

The points representing the data from the samples sintered in oil were fitted by Curve $b$, Figure I, using a simple least squares analysis. It was felt that, since there were so few points and they were on so flat a curve, the curve should not be forced to o. "Student's" $t$-test was used to test the hypothesis that the slope of the curve was zero. This hypothesis was rejected at the 99 per cent confidence limit, indicating that there is at least a statistical basis for believing that these samples gained strength over a period of time. 
The control samples, points $\mathrm{I}$ to 3 in Figure $\mathrm{I}$, were included to determine the effect of a silicone oil coating on the grain surfaces at the time of failure. Point I (mean of 7 samples) was sintered for 9 days, immersed in the oil for 5 minutes, drained for io minutes and then crushed. Point 2 was immersed in oil for I4 days then removed, placed in a saturated atmosphere for Io days, and tested. Point 3 was sintered in a saturated atmosphere for 23 days, immersed in oil for 7 days, and then tested. In each case, a correction has been applied before plotting the results to add or subtract, as appropriate, the strength they gained in the oil. To test the degree of coincidence between the control samples and the corresponding test samples "Student's" $t$-test was used to compare their mean values. In all three cases there proved to be no significant difference between the means at the 99 per cent confidence limit, i.e. the influence of a surface coating of silicone oil on the grains does not appear to affect the compressive strength of the sample significantly in any way other than by decreasing the rate of sintering. In addition, the loss of mass of the sample to the oil was determined and found to be negligible.

\section{Conclusions}

Curves $a$ and $b$ of Figure $\mathrm{I}$ indicate that the rate at which the samples immersed in silicone oil gain in strength is considerably less than that of the samples which sintered under atmospheric conditions. The difference is a factor of approximately $\mathrm{IO}^{2}$.

The rate of strengthening is proportional to the rate of the diffusion process and, as evaporation-condensation cannot occur in the samples immersed in silicone oil, it may be deduced that the rate of surface and volume diffusion is considerably lower than the rate of evaporation-condensation and that evaporation-condensation is the principal mechanism of sintering in snow exposed to a saturated atmosphere. (The assumption that the vapor pressure in the pores in the snow samples is the saturation vapor pressure is both common and reasonable.)

It is noted that the form of the equation which was found to fit the data is not compatible with the classical equations of sintering. Recently Hobbs (1965) has related the change in physical properties of snow with respect to time to the classical theory of sintering and within certain time ranges found that the rate of change was proportional to time raised to some power. He related this to the growth of bonds with respect to time. This relationship appears to hold in the middle range of the sintering process, however in the initial and final phases of the sintering process this does not seem to be applicable (also see Ballard and Feldt, r966).

If several measurements are made during the first few hours of sintering the points will generally lie below the theoretical curve expressed by equation (I) (Abele and others, I 966). It was originally thought that this was due to testing difficulties at this early stage, however, in consequence of the recent measurements made in silicone oil, this appears to be only part of the reason. In addition, the discrepancy appears to be caused by a physical process effect operating during this initial stage. If curve $b$ in Figure $\mathrm{I}$ is extended to $\tau=6$ days $(t=0)$ and compared to curve $a$ the difference in strength is striking, despite the fact that both groups of samples were prepared in the same way. Time $t=0$ is the instant the snow is compacted in the mold, which is a few seconds before the sample is placed either in the oil bath or in a saturated atmosphere. The initial strength at $t=0$ must represent the strength of the bonds created by compaction. It is believed that, because of the silicone coating surrounding the individual grains and existing bonds, no new bonds are formed during the sintering in oil, therefore, the increase in strength must be due to bond growth. This argument is supported by experiments conducted by Hobbs and Mason (1964) in which they brought ice spheres in contact beneath silicone oil and observed no neck growth over a period of several days. Under laboratory and field test conditions the initial gain in strength is very rapid, much more rapid than could be obtained by the growth of existing bonds. It is believed that the mechanism responsible for this instantaneous increase in strength is the formation of 
new bonds. The increase in new bonds becomes less important as time proceeds and eventually becomes overshadowed by the growth of existing bonds.

The primary result of these experiments is the strong evidence that evaporation-condensation is the principal process by which sintering under atmospheric conditions occurs. On the basis of these experiments it is not possible to make any quantitative estimates of the diffusion coefficients; however, some qualitative conclusions may be drawn. Assuming that the ratedetermining function is the diffusion mechanism and that therefore the only major variable in the rate equation is the diffusion coefficient, we may say that the coefficient of the sintering process in silicone oil is on the order of $1_{0}^{2}$ times smaller than the coefficient of the sintering process under atmospheric conditions. The volume diffusion coefficient $\left(\mathrm{I} \cdot 5 \times \mathrm{IO}^{-11} \mathrm{~cm}^{2} \mathrm{sec}^{-1}\right.$ at $10^{\circ} \mathrm{C}$., Dengel and Riehl, $\left.{ }^{1} 9^{6} 3\right)$ is on the order of $10^{4}$ times smaller than the transport coefficient for evaporation-condensation as defined by Hobbs and Mason (1964) and can be ruled out as a major contributing factor. If we take the surface diffusion coefficient $\left(D_{\mathrm{s}}\right)$ as being equal to approximately $\mathrm{I}^{-4} \mathrm{~cm}^{2} \mathrm{sec}^{-1}$ (personal communication from Dr. K. Itagaki) then the surface transport coefficient as defined by Hobbs and Mason will be on the order of $3 \times 10^{-8} \mathrm{~cm}^{2}$ sec. $^{-1}$. This agrees within reasonable limits with the present result which is on the order of ${ }_{10} \mathrm{O}^{-9} \mathrm{~cm}^{2} \mathrm{sec}^{-1}$, although it must be cautioned that curve $b$ has a considerable error attached to it.

\section{Acknowledgements}

The authors would like to express their appreciation to Dr. G. E. H. Ballard and Dr. K. Itagaki for their helpful comments and critical reviews of the manuscript.

MS. received 20 January 1966

\section{REFERENCES}

Abele, G., and others. 1966. Design criteria for snow runways, by G. Abele, R. O. Ramseier and A. F. Wuori.

Engineering Fournal (Engineering Institute of Canada), Vol. 49, No. 5, p. 19-24.
Ballard, G. E. H., and Feldt, E. D. 1966. A theoretical consideration of the strength of snow. Fournal of Glaciology,

Vol. 6, No. 43, p. I $59-70$.
Dengel, O., and Riehl, N. I963. Diffusion von Protonen (Tritonen) in Eiskristallen. Physik der kondensierten Materie,

Bd. I, Ht. 3, p. 191-96.
Gow, A. J., and Ramseier, R. O. 1963. Age hardening of snow at the South Pole. Fournal of Glaciology, Vol. 4,

No. 35, p. $521-36$.
Hobbs, P. V. 1965 . The effect of time on the physical properties of deposited snow. Journal of Geophysical Research,

Vol. 7o, No. 16, p. $39{ }^{\circ}-07$.
Hobbs, P. V., and Mason, B. J. 1964. The sintering and adhesion of ice. Philosophical Magazine, Eighth Ser.,

Vol. 9, No. 98, p. 181-97.
Kingery, W. D. 1960. Regelation, surface diffusion, and ice sintering. Fournal of Applied Physics, Vol. 3 r, No. 5, p. $833-38$.

Kuroiwa, D. 196r. A study of ice sintering. Tellus, Vol. 13, No. 2, p. 252-59.

Nakaya, U. 1959. Visco-elastic properties of processed snow. U.S. Snow, Ice and Permafrost Research Establishment. Research Report 58.

Ramseier, R. O. 1966 . Role of sintering in snow runway construction. Journal of Terramechanics, Vol. 3 , No. 3 .

Ramseier, R. O., and Sander, G. W. 1966. Sintering of snow as a function of temperature. [Union Géodésique et Géophysique Internationale.] Association Internationale d'Hydrologie Scientifique. Commission pour la Neige et la Glace. Division Neige Saisonnière et Avalanches. Symposium international sur les aspects scientifiques des avalanches de neige, 5-10 avril 1965 , Davos, Suisse, p. 1 19-27. 